\title{
New U.S. Geological Survey Method for the Assessment of Reserve Growth
}

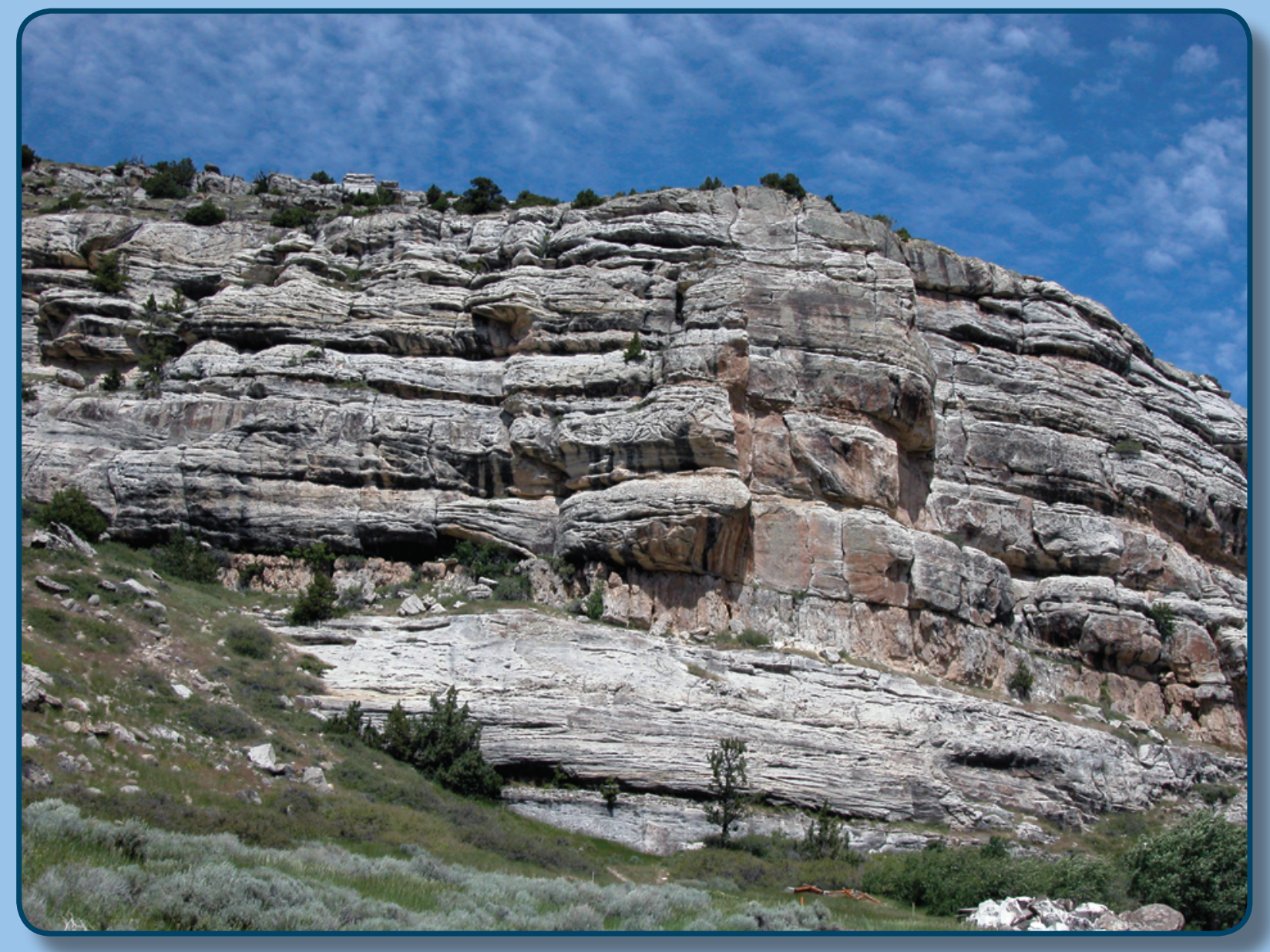

Scientific Investigations Report 2011-5163

U.S. Department of the Interior

U.S. Geological Survey 
COVER. Exposures of the Tensleep Sandstone in Sinks Canyon, near Lander, Wyoming (photograph by Christopher J. Schenk, U.S. Geological Survey). 


\section{New U.S. Geological Survey Method for the Assessment of Reserve Growth}

By Timothy R. Klett, Emil D. Attanasi, Ronald R. Charpentier, Troy A. Cook, Philip A. Freeman, Donald L. Gautier, Phuong A. Le, Robert T. Ryder, Christopher J. Schenk, Marilyn E. Tennyson, and Mahendra K. Verma (Reserve Growth Assessment Team)

Scientific Investigations Report 2011-5163 


\title{
U.S. Department of the Interior \\ KEN SALAZAR, Secretary \\ U.S. Geological Survey \\ Marcia K. McNutt, Director
}

\author{
U.S. Geological Survey, Reston, Virginia: 2011
}

For more information on the USGS - the Federal source for science about the Earth, its natural and living resources, natural hazards, and the environment, visit http://www.usgs.gov or call 1-888-ASK-USGS.

For an overview of USGS information products, including maps, imagery, and publications, visit http://www.usgs.gov/pubprod

To order this and other USGS information products, visit http://store.usgs.gov

Any use of trade, product, or firm names is for descriptive purposes only and does not imply endorsement by the U.S. Government.

Although this report is in the public domain, permission must be secured from the individual copyright owners to reproduce any copyrighted materials contained within this report.

Suggested citation:

Klett, T.R., Attanasi, E.D., Charpentier, R.R., Cook, T.A., Freeman, P.A., Gautier, D.L., Le, P.A., Ryder, R.T., Schenk, C.J., Tennyson, M.E., and Verma, M.K., 2011, New U.S. Geological Survey Method for the Assessment of Reserve Growth: U.S. Geological Survey Scientific Investigations Report 2011-5163, 8 p. 


\section{Contents}

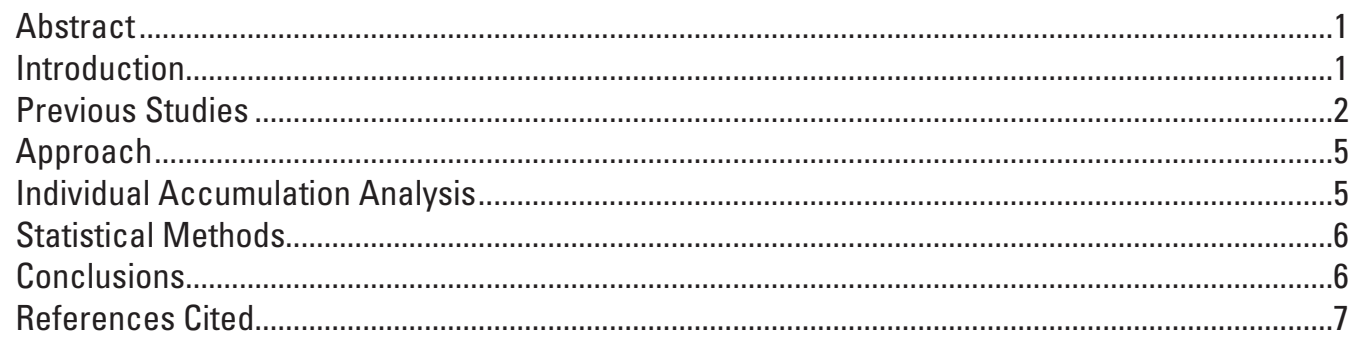

\section{Figures}

1. Diagram showing reserve growth defined as increases in successive estimates of recoverable quantities of crude oil, natural gas, and natural gas liquids in discovered fields.

2. Graphs showing reserve growth as incremental change and cumulative change relative to years since discovery. (A) Incremental change of reported recoverable quantities in accumulations of the United States by years since discovery. (B) Cumulative change of reported recoverable quantities in accumulations by years since discovery.

3. Diagram showing in-place and recovery-factor estimates statistically combined to provide probabilistic estimates of ultimate recoverable quantities. 


\section{Conversion Factors}

\begin{tabular}{lcl}
\hline \multicolumn{1}{c}{ Multiply } & By & \multicolumn{1}{c}{ To obtain } \\
\hline & Length & \\
\hline barrel $(\mathrm{bbl})$ & 0.1590 & cubic meter $\left(\mathrm{m}^{3}\right)$ \\
barrel $(\mathrm{bbl})$ & 0.136 & metric ton $(\mathrm{MT})$, average gravity \\
cubic foot $\left(\mathrm{ft}^{3}\right)$ & 0.02832 & cubic meter $\left(\mathrm{m}^{3}\right)$ \\
cubic meter $\left(\mathrm{m}^{3}\right)$ & 35.3147 & cubic feet $\left(\mathrm{ft}^{3}\right)$ \\
metric ton $(\mathrm{MT})$ & 7.33 & barrel $(\mathrm{bbl})$, average gravity \\
\hline
\end{tabular}




\title{
New U.S. Geological Survey Method for the Assessment of Reserve Growth
}

\author{
By Timothy R. Klett, Emil D. Attanasi, Ronald R. Charpentier, Troy A. Cook, Philip A. Freeman, Donald L. Gautier, \\ Phuong A. Le, Robert T. Ryder, Christopher J. Schenk, Marilyn E. Tennyson, and Mahendra K. Verma (Reserve \\ Growth Assessment Team)
}

\section{Abstract}

Reserve growth is defined as the estimated increases in quantities of crude oil, natural gas, and natural gas liquids that have the potential to be added to remaining reserves in discovered accumulations through extension, revision, improved recovery efficiency, and additions of new pools or reservoirs. A new U.S. Geological Survey method was developed to assess the reserve-growth potential of technically recoverable crude oil and natural gas to be added to reserves under proven technology currently in practice within the trend or play, or which reasonably can be extrapolated from geologically similar trends or plays. This method currently is in use to assess potential additions to reserves in discovered fields of the United States. The new approach involves (1) individual analysis of selected large accumulations that contribute most to reserve growth, and (2) conventional statistical modeling of reserve growth in remaining accumulations. This report will focus on the individual accumulation analysis.

In the past, the U.S. Geological Survey estimated reserve growth by statistical methods using historical recoverablequantity data. Those statistical methods were based on growth rates averaged by the number of years since accumulation discovery. Accumulations in mature petroleum provinces with volumetrically significant reserve growth, however, bias statistical models of the data; therefore, accumulations with significant reserve growth are best analyzed separately from those with less significant reserve growth. Large (greater than 500 million barrels) and older (with respect to year of discovery) oil accumulations increase in size at greater rates late in their development history in contrast to more recently discovered accumulations that achieve most growth early in their development history. Such differences greatly affect the statistical methods commonly used to forecast reserve growth.

The individual accumulation-analysis method involves estimating the in-place petroleum quantity and its uncertainty, as well as the estimated (forecasted) recoverability and its respective uncertainty. These variables are assigned probabilistic distributions and are combined statistically to provide probabilistic estimates of ultimate recoverable quantities. Cumulative production and remaining reserves are then subtracted from the estimated ultimate recoverable quantities to provide potential reserve growth. In practice, results of the two methods are aggregated to various scales, the highest of which includes an entire country or the world total. The aggregated results are reported along with the statistically appropriate uncertainties.

\section{Introduction}

Reserve growth is defined as the increased quantities of crude oil, natural gas, and natural gas liquids that have the potential to be added to remaining reserves in discovered accumulations through extension, revision, improved recovery efficiency, and additions of new pools or reservoirs (fig. 1). A new U.S. Geological Survey (USGS) method assesses the reserve growth potential of discovered accumulations. This method currently is in use in a new assessment of potential additions to reserves in discovered fields of the United States.

For the assessment of reserve growth in this study, the additions to reserves are considered to be technically recoverable crude oil and natural gas by use of proven technology that is currently in practice within a given trend or play, or which can reasonably be extrapolated from other geologically similar trends or plays. This study assesses only conventional accumulations and assumes no statistically specific definition of reserves. Only crude oil and nonassociated natural gas that flows to a wellbore are assessed directly. Associated/dissolved natural gas and natural gas liquids are assumed to grow by the same ratio. The overall trend for reserve growth is for higher values through time, owing to volumetrically significant fields. However, many fields show no growth of reserves, and many shrink.

In the past, the USGS estimated reserve growth by statistical methods using historical recoverable-quantity data, and the estimates of reserve growth were based on growth rates averaged by number of years since accumulation discovery (Root, 1981, 1988; Root and others, 1997; Schmoker and Klett, 2000) (fig. 2). Accumulations with the most significant reserve growth (in terms of volume) in the most mature petroleum provinces, however, bias statistical models of the 


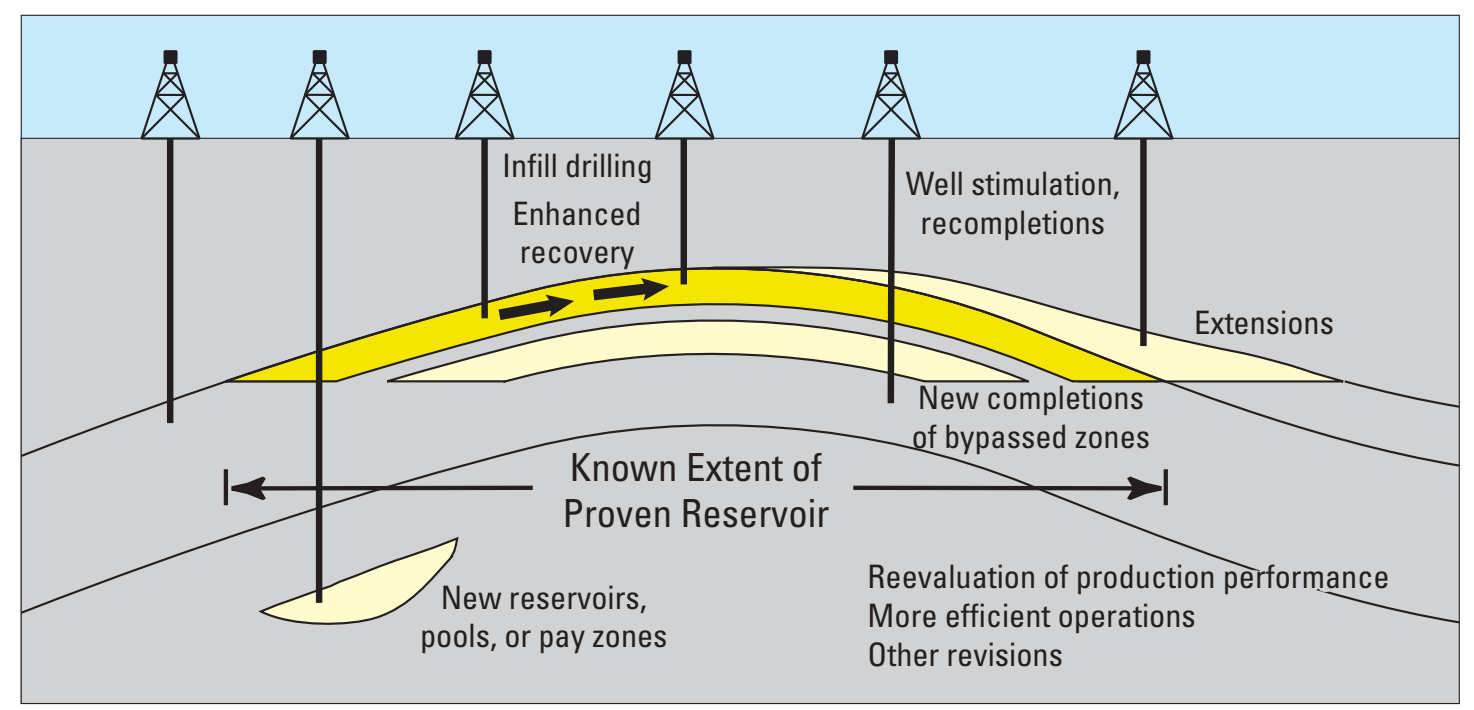

Figure 1. Diagram showing reserve growth defined as increases in successive estimates of recoverable quantities of crude oil, natural gas, and natural gas liquids in discovered fields. Reserve growth can be grouped into three activities: (1) delineation of additional in-place petroleum volumes, which increases the degree of geologic assurance (infill drilling; new reservoirs, pools, or pay zones; extensions); (2) improved recovery efficiency, which increases the degree of technological feasibility (enhanced recovery, well stimulation, recompletions, new completions of bypassed zones); and (3) revisions resulting from recalculation of viable reserves in dynamically changing economic, operating, and regulatory/political conditions, which increases the degree of economical feasibility (reevalution of production performance; more efficient operations). (Entire illustration from Klett, 2005.)

data. Therefore, estimates of reserve growth are more accurate if accumulations with significant reserve growth are analyzed separately.

Large (greater than 500 million barrels) and older (with respect to year of discovery) oil accumulations grow differently than smaller accumulations discovered later-they increase in size at greater rates later in their history rather than early (as occurs for most accumulations), thereby adversely affecting statistical methods commonly used to forecast reserve growth. The accumulations we identified primarily are in large, old oil fields, many of which are in the San Joaquin and Permian Basins (California and Texas, respectively). Removing these large accumulations results in having the less-significant accumulations biasing the estimates, in an onion-layer-like fashion. A point of diminishing returns, however, can be reached. This new assessment of reserve growth involves a two-part approach: (1) individual accumulation analysis of selected largest contributors to reserve growth, and (2) conventional statistical modeling of reserve growth in the remaining accumulations.

\section{Previous Studies}

Most published methods used to model and forecast reserve growth are statistical, based on empirical projections of past reserve-growth patterns of crude oil and natural gas fields. Being statistical and based on modeling reserve growth of large populations of accumulations, these methods account for the complex ways that petroleum volumes can be transferred to measured reserves from other reserve and resource classes. Arrington (1960) was the first to develop a method to estimate reserve growth. According to Root and Attanasi (1993), Arrington estimated annual growth of fields between year $e$ and $e^{+1}$, that is, fields that are one year older, by the growth ratio:

$$
\frac{\sum_{d} c(d, e+1)}{\sum_{d} c(d, e)}
$$

where the variable, $c(d, e)$, is the volume of crude oil or natural gas discovered in year $d$ as estimated in year $e$. The same field is represented in both the numerator and denominator.

Root and Attanasi (1993) pointed out that the underlying assumptions are that the amount of growth in any one year is proportional to the size of the field and that this proportionality constant changes as the field ages. They also indicated that field age expressed as years since discovery was used as a degree of field development because it represents a simple index of the various types of field development and also that data are more readily available.

Except for those who developed nonstatistical methods, most subsequent investigators calculated growth ratios and growth factors for fields in much the same way as Arrington (1960). Growth factors are also called "multipliers" and are 

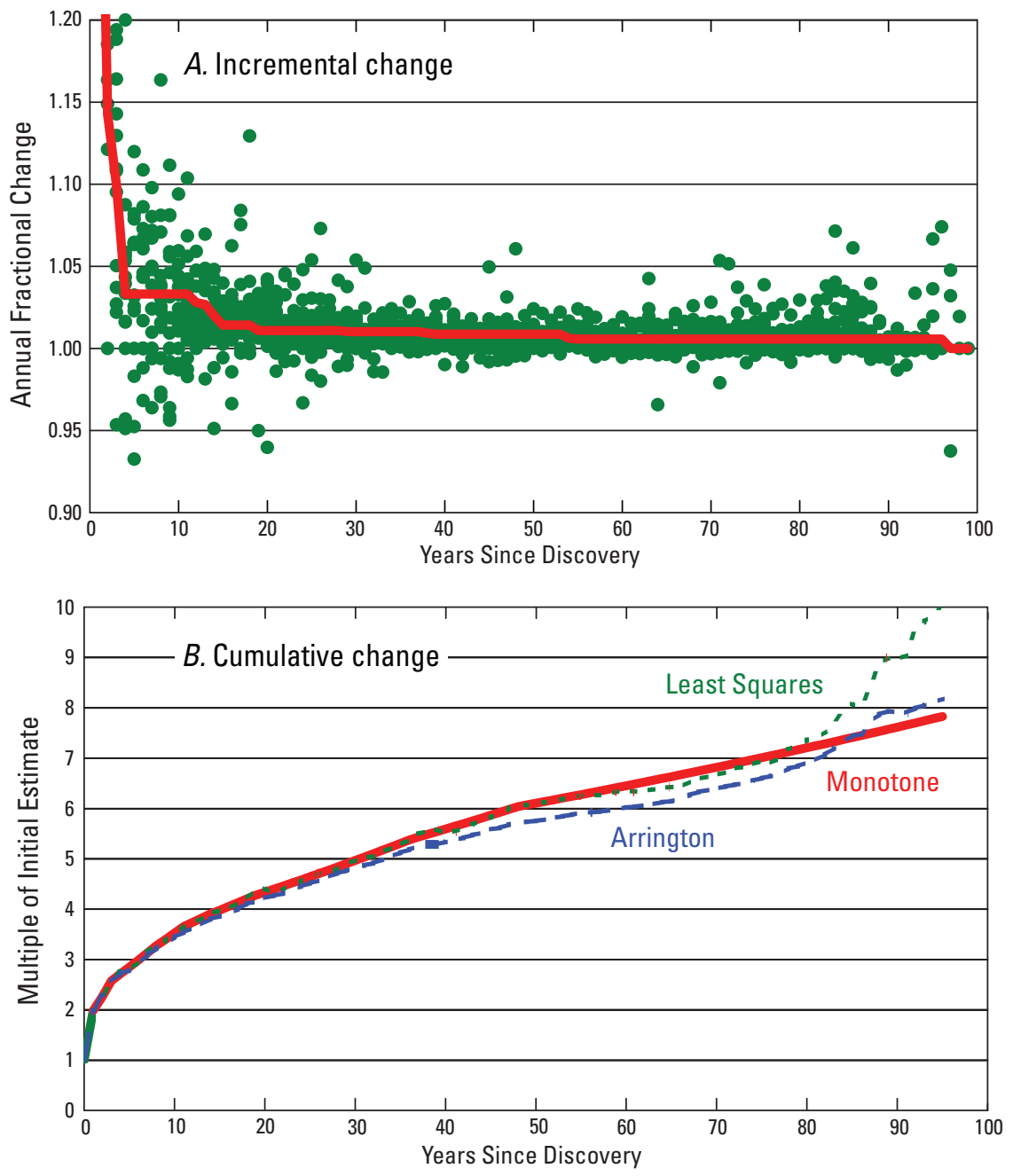

Figure 2. Graphs showing reserve growth as incremental change and cumulative change relative to years since discovery. Reserve growth can be estimated for most petroleum accumulations by statistical methods. In the past, the United States Geological Survey estimated reserve growth by statistical methods using historical recoverable quantity data, and the estimates of reserve growth were based on growth rates averaged by number of years since accumulation discovery. (A.) Incremental change of reported recoverable quantities in accumulations of the United States by years since discovery. Green dots represent annual fractional change of the summed recoverable quantities of oil accumulations. This graph was based on 17 consecutive years of data (NRG Associates, 1982 through 1998), from which 16 annual fractional change factors were calculated. Therefore, 16 points representing oil fields (green) are plotted for each year-since-discovery. An incremental reserve-growth model (red line) representing the approximate mean of the individual annual growth factors is shown for reference. (B.) Cumulative change of reported recoverable quantities in accumulations by years since discovery (modified from Attanasi, 2001). Points for every year since discovery along the incremental reserve-growth model are consecutively multiplied to construct the cumulative curves shown in this figure. Data for this graph are from production and reserves data reported from 1977 through 1996 by the Energy Information Administration (1998). 
used to calculate future reserve growth. The most current reported recoverable volumes are multiplied by the growth factors to obtain an estimate of future reserve growth. Functional forms (sometimes called "growth functions") may be assumed to relate annual field growth factors to field age. Growth factors can be given as the ratio of the accumulation size a given number of years after discovery to the size as estimated in the year of its discovery (Root and Attanasi, 1993). These are called cumulative growth factors (Hubbert, 1966; 1967; 1974; Pelto, 1973; Root, 1981; 1982; 1988; Energy Information Administration, 1990a; Lore and others, 1996; 2001; Verma and others, 2001; Verma and Ulmishek, 2003; Verma and Henry, 2004; Verma, 2003, 2005).

As seen in figure 2, from Attanasi (2001) and Klett (2003), both growth factors and functional forms flatten with time indicating that the amount of reserve growth declines as years-since-discovery increases. Statistical methods show that when the growth of reserves in fields is compared to the growth of reserves in reservoirs, growth in fields lasts longer and generally the cumulative growth multiplier is greater than in reservoirs (Attanasi and Root, 1994).

Annual estimates of recoverable volumes used to derive the growth factors are obtained from a variety of datasets.

Most report volumes only for fields located in North America. Those datasets include the following: (1) Arrington (1960) used Carter Oil's in-house estimates and provided an example of a dataset that covered a period from 1940 to 1954; (2) the American Petroleum Institute, American Gas Association, and Canadian Petroleum Association (API/AGA/CGA) (American Petroleum Institute, American Gas Association, and Canadian Petroleum Association, 1967-1980) compiled annual volumetric data in 14 yearly publications that covered the period from 1966 to 1979; (3) the Energy Information Administration compiled the Oil and Gas Integrated Field File (OGIFF), which covered the period from 1977 to 1996 (Energy Information Administration, 1990b, 1998); and (4) Nehring Associates compiled a database for the United States (Nehring Associates, 2008), which covers a period from 1985 to the present, and one for Canada (NRG Associates, 1995). The Nehring Associates' United States dataset reports annual estimates of recoverable volumes for both fields and reservoirs. IHS Energy's International Petroleum Exploration and Production Database (IHS Energy, 2009) covers the period from about 1980 to the present and provides estimates of recoverable volumes for fields outside North America. Comparable datasets are also available for the North Sea and parts of Canada.

An excellent history of the development of reserve growth methods is given by Root and Attanasi (1993). Arrington's method (developed in the early 1960s) was the first attempt to forecast reserve growth (Arrington, 1960; 1966). In the late 1960s and early 1970s, Hubbert developed a method to assess reserve growth by deriving growth factors from the API/AGA/CPA dataset that was used in the first USGS domestic petroleum resource assessment (Hubbert,
1966; 1967; 1974; Mast and Dingler, 1975). Marsh (1971) applied Arrington's method to the same API/AGA/CPA dataset. Later, Pelto (1973) developed a functional form relating reserve growth to field age much like Hubbert's. The Alberta Energy Resources Conservation Board (1968) published statistics on the annual growth of reserves, as well as average growth factors for years after discovery. Arps and others (1971) related growth factors to footage drilled since discovery instead of field age, which is an alternate way of expressing the degree of development.

In the early 1980s into the 1990s, personnel of the USGS derived growth factors by applying the Arrington method to datasets of the API/AGA/CGA, OGIFF, NRG Associates, and IHS Energy and constructed a cumulative functional form (growth function) (Root, 1981; 1982; 1988; Root and Attanasi, 1993; Root and Mast, 1993; Root and others, 1997; Attanasi and Root, 1994; Attanasi and others, 1999; Attanasi, 2001). This method was used to forecast reserve growth for subsequent USGS petroleum resource assessments. Other statistical methods were developed by (1) Lore and others (1996, 2001) with the Minerals Management Service, who derived growth factors and a function based on reserve growth of fields in U.S. Federal offshore areas; (2) the Energy Information Administration (1990a), who derived growth factors and a function based on the OGIFF dataset; and (3) the National Petroleum Council (1992; 2003), who derived growth factors and functions to include both field age and well information.

In contrast to statistical methods, in the late 1980s and early 1990s, the Potential Gas Committee (1987) and the Texas Bureau of Economic Geology (Fisher, 1991) estimated reserve growth using nonstatistical methods (Root and Attanasi, 1993). The Potential Gas Committee used a subjective volumetric-yield technique, and the Texas Bureau of Economic Geology used a combined geology and engineering approach to estimate in-place natural gas not in contact with the wellbore (National Petroleum Council, 1992).

Several recent studies have focused on particular regions. Watkins (2000) derived growth factors and functions based on reserve growth of fields of the North Sea using data reported by the United Kingdom Department of Trade and Industry and the Norwegian Petroleum Directorate. In addition, Verma and others (2001), Verma and Ulmishek (2003), Verma and Henry (2004), and Verma $(2003,2005)$ derived growth factors and functions for pools in Canada and fields in Russia based on data reported by those respective countries. Only a few studies systematically have considered the mechanisms responsible for reserve growth to estimate potential additions to reserves (for example, Tennyson, 2005). This study, however, pursues that approach. 


\section{Approach}

The primary goal of this assessment of reserve growth is to estimate the amount of potential reserve growth that could occur with current field-development practices. Such estimates represent additions in the foreseeable future rather than recoverable quantities in the sense of what ultimately may be added to reserves. Field and reservoir definitions and production/ reserves and ancillary data for the United States primarily are based on the Nehring Associates (2008) Significant Oil and Gas Fields of the United States Database (current through 2006). Well data are derived primarily from the IHS (2010) Petroleum Information/Dwights PLUS ${ }^{\mathrm{TM}}$ U.S. Well Database. Field, reservoir, and well data for accumulations outside the United States are taken primarily from the IHS (2009) International Exploration and Production Database. Other published data, such as those from the California Department of Oil, Gas, and Geothermal Resources (available online at $h t t p: / / w w w . c o n-$ servation.ca.gov/dog/) are also used. Additions to reserves are estimated based on the dataset used to characterize volumetric changes in the given accumulations. For the United States, the starting year for contemporary estimates is 2006 .

Aggregated assessment results provide estimates for the United States and the world. For the United States, accumulations are aggregated to national and regional levels. The regional level is scaled to that of the national level. Although accumulations are not aggregated to fields, all conventional accumulations within fields are assessed. This study initially focuses on reserve growth of accumulations within the United States where adequate field and reservoir data are generally available. The methods developed for estimating the nation's reserve growth then are applied to accumulations outside the United States where field and reservoir data commonly are relatively sparse.

\section{Individual Accumulation Analysis}

Accumulations that potentially are the largest contributors to reserve growth are selected for individual field analysis. The goal is to account for most of the reserve growth by this method. The individual accumulation analysis method involves estimation of the in-place quantity and its uncertainty, and the forecasted recoverability and its uncertainty (fig. 3). Minimum, median, and maximum estimates are determined for the in-place quantities, which are assigned to a lognormal distribution. The minimum parameter should not be less than the cumulative production. The maximum parameter is the 1 in 99th fractile of the lognormal distribution..

Minimum, mode, and maximum parameters are estimated for the mean recovery factor for the entire accumulation (not the entire range of possible recovery factors), which are assigned to a triangular distribution. The estimates are combined statistically to provide probabilistic estimates of ultimate recoverable quantities. During each iteration of the calculation, reported (known) recoverable quantities are subtracted from the estimated ultimate recoverable quantities to provide potential reserve growth. In some cases, shrinkage of recoverable volumes might occur in some iterations.

A protocol for the assessment of reserve growth in individual large accumulations follows:

1. The U.S. Geological Survey Reserve Growth Assessment team conducts a series of formal assessment meetings, similar to meetings to assess undiscovered petroleum resources. Only USGS personnel may attend the assessment meetings. The project team serves as Reserve Growth Assessment Team (review team) to consider input, reasoning, and supporting data.

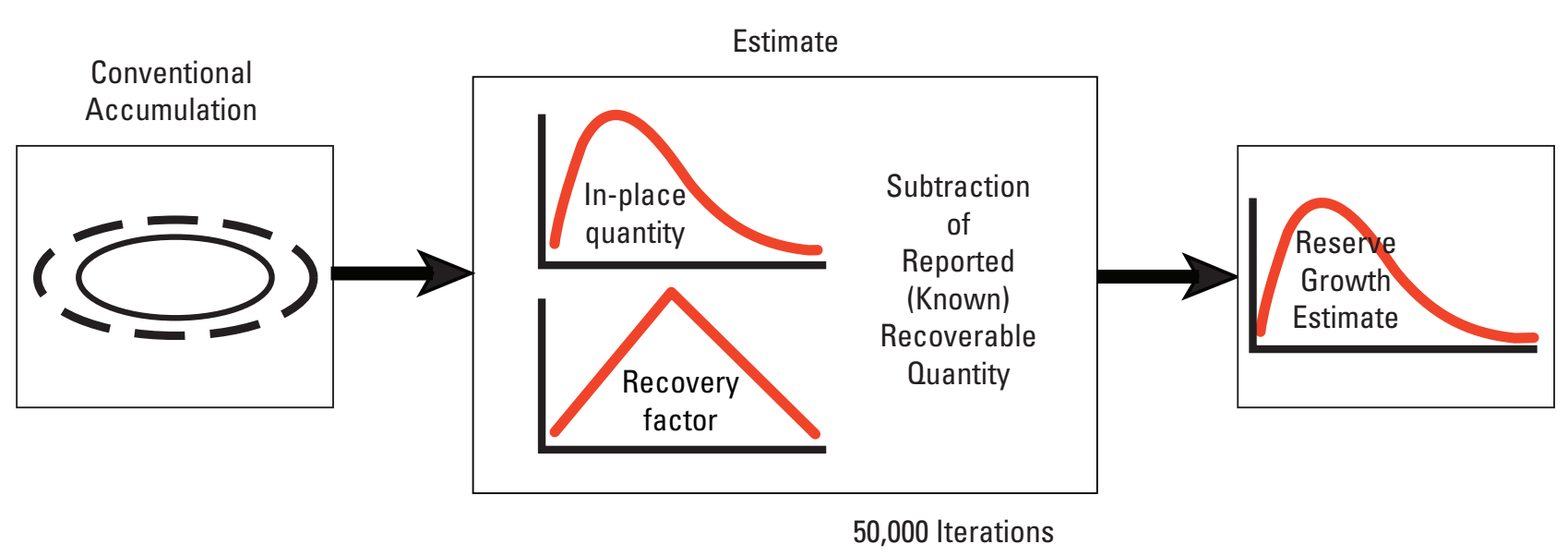

Figure 3. Diagram showing in-place and recovery-factor estimates statistically combined to provide probabilistic estimates of ultimate recoverable quantities. During each iteration of the calculation, recoverable quantities subtracted from the ultimate recoverable quantities provide estimates of potential reserve growth. 
2. Two assessment tools are used for individual accumulation analysis: (1) an input form; and (2) a set of graphs, production/reserve statistics, and maps. At the meetings, the assessor provides completed input forms for reserve-growth calculations and identifies the drivers of reserve growth from the set of graphs, statistics, and maps, to justify input.

3. The input form contains estimates of in-place quantities and recovery factors. In-place quantities are based on geologic factors and estimated from reported values. Uncertainties of those values are recorded, as well as the reasoning and justifications for uncertainty. Recovery factors are best based on engineering, reflecting the use of all applicable proven technology and current practices to develop the accumulation. Required information to aid in estimating the recovery factor includes the degree of development and whether current development technology will continue or whether proven new technologies will be implemented. Recovery factors might be greater than those presently reported, depending on the extent of current development. The recovery factors can be determined by development history of the accumulation being studied or from analog accumulations.

4. The set of graphs and statistics should include but are not limited to field-development history; reported in-place quantities and recovery factors; reported production data including cumulative production, remaining reserves, and known recoverable quantities; accumulation area; density and spacing of wells; and numbers of producing wells, injector wells, observation wells, and deeper-pool or shallower-pool wildcat wells. Descriptions of current production practices (primary, secondary, improved, and enhanced, including type of enhanced recovery), the field development history, and assumptions of future field development and recovery are required. In addition, reservoir information, geologic cross sections, maps of accumulation and reservoir boundaries, wells, lease blocks, and a list of operators are useful.

\section{Statistical Methods}

Two statistical methods to assess reserve growth, the Monotone Growth Function based on the least-squares fit having a monotonic constraint (Attanasi, 2001) (fig. 2), and a Modified Arrington Function, are used to calculate reserve growth in the accumulations not individually analyzed. In developing this new approach, these two methods were tested using the same accumulation data sets. Projections were made to 2005 and 2030 using Nehring Associates data current through 2000. In addition, reserve growth was estimated in terms of years since accumulation discovery and years since first production. The tests show that the two statistical methods accurately predicted volumes reported in 2005. Estimates of reserve growth by the two methods were similar for the 5-year forecasts, becoming less similar in the longer term (as for the 30 -year forecast and beyond).

For this new study, the statistical models are applied to the historical recoverable quantity data for remaining accumulations, and the results are evaluated by the assessment review team. Results from the individual accumulation analysis and the statistical methods are then aggregated.

\section{Conclusions}

This project estimates reserve growth, over the foreseeable future, in accumulations that are the largest contributors to reserve growth. The final product is to be a table of reservegrowth estimates for USGS-defined regions and for the United States as a whole. Results from the two methods are to be aggregated at various scales, the highest of which includes country or world scales, and reported along with the largest meaningful uncertainty. 


\section{References Cited}

American Petroleum Institute, American Gas Association, and Canadian Petroleum Association, 1967-1980, Reserves of crude oil, natural gas liquids, and natural gas in the United States and Canada as of December 31 [annual reports]: Washington, D.C., American Petroleum Institute, v. 25-34.

Arps, J.J., Mortada, M., and Smith, A.E., 1971, Relationship between proved reserves and exploration effort: Journal of Petroleum Technology, v. 23 (June 1971), p. 671-675.

Arrington, J.R., 1960, Predicting the size of crude reserves is key to evaluating exploration programs: Oil \& Gas Journal, v. 58, no. 9 (19 February), p. 130-134.

Arrington, J.R., 1966, Estimation of future reserve revision in current fields, in Transactions of the West Texas Geological Society's Symposium, Midland, Tex., October 20-21, 1966, Economics and the petroleum geologist: West Texas Geological Society, no. 66-53, p. 16-30.

Attanasi, E.D., 2001, Inferred oil and gas reserve estimates for the United States: U.S. Geological Survey Open-File Report 01-447, $15 \mathrm{p}$.

Attanasi, E.D., and Root, D.H., 1994, The enigma of oil and gas field growth: American Association of Petroleum Geologists Bulletin, v. 78, no. 3, p. 321-332.

Attanasi, E.D., Mast, R.F., and Root, D.H., 1999, Oil, gas field growth projections-Wishful thinking or reality?: Oil \& Gas Journal, v. 97, no. 14 (5 April), p. 79-81.

Energy Information Administration, 1990a, The domestic oil and gas recoverable resource base- - Supporting analysis for the national energy strategy: Energy Information Administration, SR/NES/90-05, $56 \mathrm{p}$.

Energy Information Administration, 1990b, U.S. oil and gas reserves by year of field discovery: Energy Information Administration DOE/EIA-0534, 137 p.

Energy Information Administration, 1998, Oil and gas integrated field file (through 1996): Energy Information Administration, proprietary digital database.

Energy Resources Conservation Board [Alberta], 1968, Reserves of crude oil, gas, and natural gas liquids and sulphur, Province of Alberta: Calgary, Alberta, Energy Resources Conservation Board Report 69-18 (31 December 1968).

Fisher, W.L., 1991, Future supply potential of U.S. oil and natural gas: The Leading Edge, Tulsa, Okla., v. 10, no. 12 (December), p. 15-21.
Hubbert, M.K., 1966, Degree of advancement of petroleum exploration in the United States, in Transactions of the West Texas Geological Society's Symposium, Midland, Tex., October 20-21,1966, Economics and the petroleum geologist: West Texas Geological Society, no. 66-53, p. 136-163.

Hubbert, M.K., 1967, Degree of advancement of petroleum exploration in the United States: American Association of Petroleum Geologists Bulletin, v. 51, no. 11, p. 2207-2227.

Hubbert, M.K., 1974, U.S. energy resources-A review as of 1972, part 1 of a National Fuels and Energy Policy study: Washington, D.C., Government Printing Office, U.S. 93rd Congress, 2nd Session, Senate Committee on Interior and Insular Affairs, Serial No. 93-40 (92-75).

IHS, 2009, International Exploration and Production Database: IHS (Information Handling Services); database available from IHS, 15 Inverness Way East, D205, Englewood, CO 80112, U.S.A.

IHS, 2010, Petroleum Information/Dwights PLUSTM United States well data: IHS (Information Handling Services); database available from IHS, 15 Inverness Way East, D205, Englewood, CO 80112, U.S.A.

Klett, T.R., 2003, Graphical comparison of reserve-growth models for conventional oil and gas accumulations, in Dyman, T.S., Schmoker, J.W., and Verma, M.K., eds., Geologic, engineering, and assessment studies of reserve growth: U.S. Geological Survey Bulletin 2172-F, 63 p. [also available at http://geology.cr.usgs.gov/pub/bulletins/ b2172-f/, accessed August 2011].

Klett, T.R., 2005, United States Geological Survey's reservegrowth models and their implementation: Natural Resources Research, v. 14, no. 3, p. 249-264.

Lore, G.L., Brooke, J.P., Cooke, D.W., Klazynski, R.J., Olson, D.L., and Ross, K.M., 1996, Summary of the 1995 assessment of conventionally recoverable hydrocarbon resources of the Gulf of Mexico and Atlantic Outer Continental Shelf: Minerals Management Service, Outer Continental Shelf Report MMS 96-0047, 41 p., plus 5 appendixes.

Lore, G.L., Marin, D.A., Batchelder, E.C., Courtwright, W.C., Desselles, R.P., Jr., and Klazynski, R.J., 2001, 2000 assessment of conventionally recoverable hydrocarbon resources of the Gulf of Mexico and Atlantic Outer Continental Shelf as of January 1, 1999: Minerals Management Service, Outer Continental Shelf Report MMS 2001-087 [also available at www.gomr.mms.gov, accessed August 2011].

Marsh, R.G., 1971, How much oil are we really finding?: Oil \& Gas Journal, v. 69, no. 14 (5 April), p. 100-104. 
Mast, R.F., and Dingler, J., 1975, Estimates of inferred + indicated reserves for the United States by states, in Miller, B.M., Thomson, H.L., Dolton, G.L., Coury, A.B., Hendricks, T.A, Lennartz, F.A., Powers, R.B., Sable, E.G., and Varnes, K.L., eds., Geological estimates of undiscovered recoverable oil and gas resources in the United States: U.S. Geological Survey Circular 725, p. 73-78.

National Petroleum Council, 1992, Source and supply-The potential for natural gas in the United States, Volume II: Washington, D.C., National Petroleum Council, 400 p.

National Petroleum Council, 2003, Balancing natural gas policy - Fueling the demands of a growing economy, Volume IV, Supply Task Group report: Washington, D.C., National Petroleum Council, p. 2-102-2-105.

Nehring Associates, 2008 [includes data current as of December 2006], The significant oil and gas fields of the United States: Nehring Associates, Inc., P.O. Box 1655, Colorado Springs, CO 80901, U.S.A.

NRG Associates, 1995, The significant oil and gas fields of Canada database: Nehring Associates, Inc., P.O. Box 1655, Colorado Springs, CO 80901, U.S.A.

Pelto, C.R., 1973, Forecasting ultimate oil recovery, in Symposium on Petroleum Economics and Evaluation: Dallas, Tex., Society of Petroleum Engineers, Dallas Section, The American Institute of Mining, Metallurgical, and Petroleum Engineers, p. 45-52.

Potential Gas Committee, 1987, Potential supply of natural gas in the United States (December 31, 1986): Potential Gas Agency, Colorado School of Mines, Golden, CO, 119 p.

Root, D.H., 1981, Estimation of inferred plus indicated reserves for the United States, in Dolton, G.L., Carlson, K.H., Charpentier, R.R., Coury, A.B., Crovelli, R.A., Frezon, S.E., Khan, A.S., Lister, J.H., McMullin, R.H., Pike, R.S., Powers, R.B., Scott, E.W., and Varnes, K.L., eds., Estimates of undiscovered recoverable conventional resources of oil and gas in the United States: U.S. Geological Survey Circular 860, p. 83-87.

Root, D.H., 1982, Historical growth of estimates of oil- and gas-field sizes: Oil and Gas Supply Modeling, National Bureau of Standards Special Publication 631, p. 350-368.

Root, D.H., 1988, Inferred and indicated reserves, in U.S. Geological Survey and Minerals Management Service, National assessment of undiscovered conventional oil and gas resources, USGS-MMS [working paper]: U.S. Geological Survey Open-File Report 88-373, p. 100-105.

Root, D.H., and Attanasi, E.D., 1993, A primer in field-growth estimation, in Howell, D.G., ed., The future of energy gases: U.S. Geological Survey Professional Paper 1570, p. 547-554.
Root, D.H., and Mast, R.F., 1993, Future growth in known oil and gas fields: American Association of Petroleum Geologists Bulletin, v. 77, no. 3, p. 479-484.

Root, D.H., Attanasi, E.D., Mast, R.F., and Gautier, D.L., 1997, Estimates of inferred reserves for the 1995 National Oil and Gas Resources Assessment: U.S. Geological Survey Open-File Report 95-75-L, 29 p.

Schmoker, J.W., and Klett, T.R., 2000, Estimating potential reserve growth of known (discovered) fields - A component of the USGS World Petroleum Assessment 2000, in U.S. Geological Survey World Energy Assessment Team, eds., U.S. Geological Survey World Petroleum Assessment 2000: U.S. Geological Survey Digital Data Series DDS-60, 4 CDROMs, $20 \mathrm{p}$.

Tennyson, M.E., 2005, Growth history of oil reserves in major California oilfields during the twentieth century, in Dyman, T.S., Schmoker, J.W., and Verma, M.K., eds., Geologic, engineering, and assessment studies of reserve growth: U.S. Geological Survey Bulletin 2172-H, 15 p. [also available at http://geology.cr.usgs.gov/pub/bulletins/b2172-h/, accessed August, 2011].

Verma, M.K., 2003, Modified Arrington method for calculating reserve growth-A new model for United States oil and gas fields, in Dyman, T.S., Schmoker, J.W., and Verma, M.K., eds., Geologic, engineering, and assessment studies of reserve growth: U.S. Geological Survey Bulletin 2172D, 14 p. [also available at http://geology.cr.usgs.gov/pub/ bulletins/b2172-d/, accessed August 2011].

Verma, M.K., 2005, A new reserve growth model for United States oil and gas fields: Natural Resources Research, v. 14, no. 2 , p. $77-89$.

Verma, M.K., and Henry, M.E., 2004, Historical and potential reserve growth in oil and gas pools in Saskatchewan, in Summary of Investigations 2004: Regina, Saskatchewan Geological Survey, Saskatchewan Industry Resources, Miscellaneous Report 2004-4.1, Volume I, CD-ROM, Paper A-1, $20 \mathrm{p}$.

Verma, M.K., and Ulmishek, G.F., 2003, Reserve growth in oil fields of West Siberian Basin, Russia: Natural Resources Research, v. 12, no. 2, p. 105-119.

Verma, M.K., Ulmishek, G.F., and Gilbershtein, A.P., 2001, Slower reserve growth rates observed in Volga-Ural Province, Russia: Oil \& Gas Journal, v. 99, no. 9 (26 February), p. 34-44.

Watkins, G.C., 2000, Characteristics of North Sea oil reserve appreciation: Cambridge, Massachusetts Institute of Technology, Center for Energy and Environmental Policy Research Paper MIT-CEEPR 2000-008 [working paper], 33 p. 
Publishing support provided by:

Denver Publishing Service Center

For more information concerning this publication, contact: Center Director, USGS Central Energy Resources Science Center Box 25046, Mail Stop 939

Denver, CO 80225

(303) 236-1647

Or visit the Central Energy Resources Science Center Web site at: http://energy.cr.usgs.gov/ 
题

, 